\title{
Stand-up Comedy Humor Discourse in Local Perspective in Indonesia
}

\author{
Aris Badara* \\ Indonesian Language Education Department, Halu Oleo University, Indonesia \\ Corresponding Author: Aris Badara, E-mail: arisbadara71@yahoo.co.id
}

\section{ARTICLE INFO}

Article history

Received: July 17, 2018

Accepted: October 14, 2018

Published: December 01, 2018

Volume: 7 Issue: 7

Advance access: October 2018

Special Issue on Language \&

Literature

Conflicts of interest: None

Funding: None

\begin{abstract}
Examining stand-up comedy humor discourse in local perspective in Indonesia is fascinating due to its uniqueness and complexity. This kind of discourse has some specific characteristics in terms of its creation and language use. A qualitative study was conducted with the data source from stand-up comedy records staged in 2016 by the stand-up comedy local community in Kendari, Southeast Sulawesi. The data were reduced to obtain the funniest humor discourse. Furthermore, the data were analyzed based on the creation technique and the construction elements of humor discourse in terms of linguistic and non-linguistic context. The research findings showed that the creation technique and the construction elements of stand-up comedy humor discourse in local perspective in Indonesia were in line with the general concepts and theories of humor discourse creation techniques namely: (a) rhetoric, (b) tone variation, (c) irony, (d) language misunderstanding, (e) wordplay, (f) verbal jokes, (g) sarcasm, (h) satire, (i) sexual satire, and (j) deception. In addition, the results confirmed that the most widely used of creation techniques were rhetoric, wordplay, and deception. The three techniques are more pronounced than other techniques due to the local comics circumscribed public speaking capability.
\end{abstract}

Key words: Stand-up Comedy Humor Discourse, Punch, Creation Techniques of Humor Discourse, Elements Of Humor Discourse

\section{INTRODUCTION}

In a general term, stand-up comedy is an art that is delivered individually in front of the live audience. Specifically, standup comedy can also be interpreted as humorous stage where generally the comedian speaks directly to the audience. Stand-up comedy becomes more attractive because in producing jokes the comedian mostly relies on speaking proficiency rather than body language. This is in accordance with the development of Indonesian's young generation today which is more inclined to listen the story directly rather than to read. As a result, it makes stand-up comedy becomes more favorable amongst youth.

In addition, its ability to attract audiences' critical thinking also contributes to its familiarity amongst youth. It is in line with Siwi (2016:2) who states that comics in stand-up comedy rely on their intelligence to create a good humor. It indicates that the joke materials on stand-up comedy are original, intelligent, and amusing. They can provoke the audience to think critically without losing the sense of its nature and humor. As a part of humor, stand-up comedy materials are often used as a medium for critics and persuasion. It can be utilized as an effective means of persuasion to influence the audiences.

In the present day, stand-up comedy performances in Indonesia are mostly aired on national television and attract many viewers on video sharing sites like YouTube. Its popularity draws significant attention and promotes many stand-up comedy communities, not only in some major cities for instance Jakarta or Surabaya but also in small cities. These communities regularly perform the stand-up comedy with their own local characteristics. They establish communities based on their origin or culture and social life similarity as well.

The jokes material at the local stand-up comedy communities usually conveys some local phenomena, local politics and social issues. The comics present their material slickly and attractively to produce an interesting humor. It makes the audiences attracted to watching the stand-up comedy performance. Besides, it becomes an attraction especially for local students.

Local patterned humor in local area has a unique and complex matter. It has its own characteristics from the point of its creation as Yuniawan (2005) points out that the humor is not always the same for everyone because the humor is personal and communal. The example of the unique language use perspective in stand-up comedy humor discourse in Kendari is illustrated below:

(01) "Doti-Doti, so be careful for those who do not laugh. If you do not laugh, you will be turned to stone, butter head, or onde-onde on here (pointing to his head). Be careful!"

(Data of stand-up comedy discourse, 2016)

Published by Australian International Academic Centre PTY.LTD.

Copyright (c) the author(s). This is an open access article under CC BY license (https://creativecommons.org/licenses/by/4.0/)

http://dx.doi.org/10.7575/aiac.ijalel.v.7n.7p.222 
The example demonstrates the uniqueness of humor creation by using the terms Doti and onde-onde; however, for those who are not familiar with the communal culture in Kendari will certainly difficult to find the humor.

Generally, humor is a broad term that refers to anything that people say or do is perceived as funny and tends to make others laugh, as well as the mental processes that go into both creating and perceiving such an amusing stimulus, and also the affective response involved in the enjoyment of it (Martin, 2007: 5). In particular, humor can be interpreted as ridiculousness or senseless speech that evoked laughter (Berger, 1998: 3). Although humor is often met by the incongruity, the humor requires the language understanding to enable streamlined communication as well.

Furthermore, to represent the contextual definition of humor related to its unique and complexity, it must fulfill one or more elements, namely: (a) surprise, (b) embarrassment creation, (c) problem exaggeration, and (d) obscurantism (Claire, 1984). The elements will create humor if they are supported by creative verbal actions or funny performances. Humor, in terms of language use, also has characteristic to apply distorted language which intend to strengthen the humor. Based on the explanation, humor in this research can be defined as a spoken language, affirmed by verbal or action, which meets the humorous elements and communally understood by audiences.

Related to the concept of stand-up comedy, Indonesia has its own distinct concept compares to the other countries, particularly United States as the birthplace of standup comedy. It is caused by the existence of traditional arts for example ketoprak, ludruk, and wayang (Setyaningsih, 2013). In America, stand-up comedy began around the $1800 \mathrm{~s}$ in form of theater. The famous theater at the time was The Minstral Show hosted by Thomas Dartmouth Rice or commonly called Diddy (Rodasaut, 2013).

The difference in the origin of stand-up comedy comes with some different definitions. In other countries, for instance, stand-up comedy is interpreted as "an inherently rhetorical discourse; it strives not only to entertain, but to persuade, and the comics will be successful in their craft when they can convince the audience to look at the world through their comic vision" (Greenbaum, 1999). Nevertheless, in Indonesia, the definition of stand-up comedy still remains unclear. Therefore, this study defined stand-up comedy as a humor that discusses specific topics to entertain as well as to deliver criticisms made by comics in front of the live audience.

Based on the aforementioned discussion of discourse, humor, and stand-up comedy, the researcher defined stand-up comedy humor discourse in this study as the live funny speech, sometimes supported by body movements, delivered by comic to entertain or to criticize by producing humor.

In terms of humor discourse creation, for example proposed by Wilson (1979: 10), Sudjatmiko (1992: 70), Wijana (1996: 6, 2004: 21), Rustono (1998: 47-55), Raskin (1985: 222), Raskin and Attardo (1991), it can be summarized into three main theories: (a) liberation theory, (b) conflict theory, and (c) nonconformity theory. This research referred to these theories eclectically; however, language elements are applied as the main analysis. It is based on the fact that verbal components take dominant in stand-up comedy humor discourse. It is confirmed by Raskin (1985: 56) who argues that the humor of a text can emerge due to the engagement of language elements, namely: a presupposition, and/or implicative, and/or speech act, and/or the world.

The term of stand-up comedy discourse in this study is based on the discourse study introduced by van Dijk (1977) who argues that the discourse is the abstract theoretical construct. His opinion is in line with Crystal (1987: 116) who states that discourse is limited to the structure of oral language only; however, referring these opinions, the definition and the use of both discourse and text in Indonesian language (hereafter called Indonesian) linguistics remain unclear and are often overlapping. Therefore, this study invoked Badara's (2013) opinion that examines the discourse in terms of positivism empirical view, constructivism view, critical view, and concludes that the discourse is the language used in communicating.

Based on the previous explanation, the researcher investigated the creation technique and construction elements of stand-up comedy humor discourse in local perspective in Indonesia.

This research was expected to be theoretically significant for the linguistic theory development, namely: (a) a description of creation technique and construction elements of stand-up comedy humor discourse in local perspective, and (b) one of references relating to the humor discourse of stand-up comedy. It was also expected to be practically significant to contribute as the source for further research in an effort of stand-up comedy humor discourse utilization for a variety of purposes. Furthermore, theoretical and conceptual constructions were employed to examine the aforementioned research problems.

\section{METHODOLOGY}

This study was qualitative study which referred to Creswell (1994). The researcher interpreted and described the data of stand-up comedy records staged in 2016 by the standup comedy local community in Kendari, Southeast Sulawesi.

The data in this study is the fragments of stand-up comedy humor discourse from stand-up comedy staging performed by local comics in Kendari. The data is reduced to obtain the funniest fragment of stand-up comedy humor discourse or commonly known as punch. Furthermore, the data were analyzed based on the creation technique which refers to Berger's opinion (1993). After obtaining the creation elements of stand-up comedy humor discourse, the researcher conducted a depth analysis related to the elements that build the humor discourse, both of linguistic and non-linguistics contexts.

Data were collected by using documentation technique through attentive observation and noting method, and were supported by recording technique. The attentive observation method was used because the data obtained through attentive procedures (Sudaryanto, 1993: 2). Data analysis in this re- 
search was matching method (Sudaryanto, 1993: 13). In this case, the identity of the research's objects was determined by their correspondence, alignment, appropriateness, suitability, or similarity to the determinant device which becomes its standardization as well.

\section{RESEARCH RESULTS}

\section{The Creation Technique and Construction Elements of Stand-up Comedy Humor Discourse in Local Perspective in Indonesia}

Berger (1993) had proposed ten humor creation techniques. Those techniques appeared in the creation of stand-up comedy humor discourse in Indonesian local perspective. The creation techniques of humor discourse are divided into: (a) rhetorical speech, (b) tone variation, (c) irony, (d) language misunderstanding, (e) wordplay, (f) verbal joke, (g) sarcasm, (h) satire, (i) sexual satire, and (j) deception.

\section{The creation technique of humor discourse through rhetorical speech}

Rhetoric, in Indonesia called berbicara muluk (grandiloquent) or in English called bombastic, is a technique of exaggerated humor creation in responding to something or someone. The example below can be incorporated into the humor discourse created by rhetorical speech.

(02) "Be careful to ridicule people! A person who grows in mockery will become an extraordinary person. Do not give applause! This is not a seminar!"

(Data of stand-up comedy discourse, 2016)

The next rhetorical comedy was used by comics on standup comedy as follows.

(03) "What you see is just a case/cover, friends. Do not buy an expensive mobile phone just because of its case. You need to look at its processor or its application. It is been proven, beauty and charm do not affect the quality of one's relationships"

(Data of stand-up comedy discourse, 2016)

The phrase "be careful to ridicule people!" (02), actually points to the comic himself because he realized that most of local comics, including him, are still lack of experience and less capable in public speaking. Self-embarrassing sentences often occur amongst local comic to create jokes; however, it lessens the humor sense since they are expected to be able to utilize the power of words or phrases as well as action in every stand-up comedy stage. Based on the audiences' point of view, the statement (02) was meant to be a warning to not mock the comic. The phrase "be careful to ridicule people!" created a humor because it has fulfilled the element of obscurantism and element of problem exaggeration proposed by Claire (1984). Exaggeration and obscurantism in context of the phrase (02) associated with "person who is often mocked will become extraordinary person". Although there is one who grows up to be extraordinary, it is just casuistry. In fact, extraordinary person is the one who works hard or try hard to become extraordinary.

In terms of language irregularities, it can be explained that comic used imperative sentences that warned the audience to not mock or to ridicule people, "be careful to ridicule people!" In the context of stand-up comedy humor discourse such symptoms can be classified into the rhetorical humor discourse which is constructed in the form of recreate humor discourse (Ambarwati, 2016). The phrase, "be careful to ridicule people!" was actually an unimportant statement, in fact, comics solely wanted to create a funny situation by expressing the phrase.

If the phrase (02) was conveyed in the context of producing humor with a style of "pride" or behaving like a "wise" person, then such a situation would emerge a humor. Moreover, another cause that emerged a humor in phrase (02) was because it reversed back with the initial impression created by comics. He initially acted like a person who was often mocked, then said, "Be careful to ridicule people! A person who grows with mockery will become an extraordinary person"

Besides containing recreational rhetorical humor discourse, in phrase (03), it was classified as discourse with rhetorical mode with the construct of persuasive humor discourse as well. This kind of discourse tries to influence or persuade people. In this case, comic persuaded the audience to not judge something based on "the cover/case". In context of local culture in Indonesia, there is a famous phrase, "do not just look at the cover, look at the contents as well". The phrase means do not be too quick to judge a person from his or her look or appearance.

The humor discourse (03) emerged humor because the comic used metaphor by comparing man to inanimate objects. In the discourse (03) he compared choosing a partner to choosing a mobile phone. He highlighted through the phrases: "What you see is just a case, friends", "Do not buy expensive mobile phones just because of its case, look at the processor or its specification". Using the metaphor of mobile phone successfully produce the laughter. It becomes interesting and humorous for the audiences since the metaphor strongly correlate with smartphone "fever" amongst Indonesian teenagers.

\section{The creation technique of humor discourse through tone variation}

According to Berger (1993), humor created through tone variation is the humor created by playing with the language tone by changing one sound of a word in order to invite the response of laughter. Here is an example of stand-up comedy humor discourse created through the tone variation delivered by comic.

(04) "Let me introduce myself, my name is La Ode Raimudin, you can call me? (the audience answered "Ray"). Thank you so much. I come from Wakatobi. Do you know Wakatobi? It is near from Wakapolsek, and Wakabayasi.

(Data of stand-up comedy discourse, 2016)

The phrase (04) is using three words that have similarities in the early syllables, Wakatobi, Wakapolsek, Wakabayasi. The word 'waka' which has similar sounds to the three words used by the comic produces humor because in linguistic theory, the sounds at the first syllable of the three previous 
words should have the same meaning and form; however, in this case, the three words mentioned by the comics have no relation in meaning and form at all.

Firstly, 'Wakatobi', is the name of one of districts in Southeast Sulawesi Province which is an acronym of 4 island group names, Wangi-wangi Island, Kaledupa Island, Tomia Island, Binongko Island. Secondly, 'Wakapolsek' is an acronym of 'deputy chief of sector police' who is in charge of assisting the police chief in carrying out his duties of supervising, controlling, coordinating the implementation of the tasks of all police units at the sector/ sub-district level. Thirdly, 'Wakabayashi' is one of anime characters from Japan. These symptoms have deviations of form and meaning that cause the occurrence of pragmatic and semantic violations. Pragmatic deviations occur because of the phrase "... near from Wakapolsek, also near from Wakabayasi." 'Wakatobi' as the name of one of districts in Southeast Sulawesi, was not likely to be near from Wakapolsek which is the name of the office, nor was it possible to be close to Wakabayasi which is the name of an anime character. Therefore, it can be concluded that the data on humor discourse (04) produced the deviations of meaning. The phenomenon is in line with Wijana (2003) who stated that the tone variation is a form of language that contains various language structure deviations. These kinds of violations are pragmatic which intended to achieve various purposes, for instance joking, criticizing, advising, banning and other purposes that are often not easily identified.

\section{The creation technique of humor discourse through irony}

Berger (1993) stated that creation technique of humor through irony is the humor that is created by expressing something that means something else or the opposite from what is clearly known by the listener. It can be seen in the following humor discourse.

(05) Look at this city's tagline "Kendari is a pious town" "Alhamdulillah, where is it exactly written? It is written in Kendari Beach. It is very strange, sacred sentence is put in the proper place"

(Data of stand-up comedy discourse, 2016)

The stand-up comedy humor discourse (05) was created by using creation technique of irony. The irony in the fragment (05) is marked by the word Alhamdulillah. The word has no equivalent in Indonesian but has been absorbed into Indonesian. The word Alhamdulillah comes from the Arabic, which is an expression of praise to God for the grace given or the good that happens or is accepted by someone. Kendari Beach, in fact, is a tourist spot as well as a special spot for girls and boys on weekends. Comparing these two different situations emerges irony as well as causing humor. Comic said "Alhamdulillah" as an expression of praise to God, but actually comic expresses regret why the religious tagline of "Kendari is a pious town" is displayed in Kendari Beach. The appropriate expression for such situation supposed to be astagfirullah or Astagfirullah hal'adzim which for Muslims is an expression for asking God's salvation from seeing or making mistakes. The statement is the iro- ny statements, which is a statement that means contrary to what it says.

\section{The creation technique of humor discourse through language misunderstanding}

The following discourse (06) demonstrates the humor creation by exploiting misunderstandings.

(06) "Good morning. Good morning. In this opportunity I want to tell you about our restlessness as settler. "

(Data of stand-up comedy discourse, 2016)

The data of stand-up comedy humor discourse (06) emerged laughter because the stand-up comedy was held at night. The comic deliberately greeted the audience by saying "good morning" although the situation took place at night. These kinds of situations created the impression that comics cannot distinguish between morning and night. These paradoxical expressions are intended to inflict humor. Besides, the humor is emerged in the phrase (06) because it fulfilled the element of impropriety as proposed by Claire (1984). In fact, there is an expression in Indonesian culture that says, "Do not say good night at sunrise, unless you want to make laughter." Thus, the stand-up comedy humor discourse data (06) can be incorporated into the humor discourse of standup comedy created through language misunderstanding techniques. Furthermore, the data of humor discourse (06) also demonstrated an expression to occur a humor by producing language misunderstanding.

(07) "Tonight I am very proud to be able to perform in front of you all; especially in front of you (comic pointed one of audiences). Not you! But the guy behind you"

(Data of stand-up comedy discourse, 2016)

The discourse (07) was created by using language misunderstanding. The comic made one of female audiences thought that she was the one who appointed by the comic which was apparently mistaken because he appointed a male audience, "Not you! But the guy behind you". These kinds of situations created laughter for teenagers in Indonesia since it is commonly acknowledge in that man will only proud of appearing in front of woman in public, not the contrary. This joke strengthened by the embarrassment taken by a "victim" male audience who appointed by the comic as well.

Overall, the humor discourse (07) emerges laughter because of the misunderstandings that deliberately used by the comic. The comic created a misconception in interpreting the situation or in the pragmatic field is called a deviation of the maxim of relevance.

\section{The creation technique of humor discourse through wordplay}

The creation technique of humor discourse through wordplay according to Berger (1993) is the creation of humor by playing the meaning of the word to the ambiguous meaning. Below is a stand-up comedy humor discourse created by comic by employing wordplay.

(08) "Ida is a beautiful girl. I approached her and asked, "Ida! May I ask for your phone number? "Well, I do not bring my mobile phone". "Please focus on my ques- 
tion. May I ask for your phone number?" She said "I do not bring my mobile phone". I was confused and then I asked "Ida! Where do you live? "I do not bring my house". I said "Ida! I do not want to borrow your mobile phone. I asked for your phone number, can I have your phone number?" She immediately said "Sorry, I cannot memorize my phone number" then I said "what about your name?" she said "I cannot memorize it as well. Who am I? I do not have a name". "Hearing her answer, I spontaneously said "Ok. How pity you are"

(Data of stand-up comedy discourse, 2016)

Fragment (08) becomes humorous because comic flip through words. Flipping words is one of humor discourse creation signs through the word meaning play. The comic flipped the phrase: "Ida! May I ask for your phone number?" "Well, I do not bring mobile phone" "Ida! Where do you live?" I do not bring my house" "What about your name?.". The conversation demonstrated an unserious and a humorous dialogue. Comic created humor discourse by playing the words meaning in monologue. The comic demonstrated the word meaning play in the phrase "Ida! May I ask for your phone number? "Well, I do not bring my mobile phone." He continued in phrases "Please focus on my question "May I ask for your phone number?" She said "I do not bring my mobile phone". The phrase emerges laughter because the conversation clearly gave hints to the audiences that the woman who was asked by the comic in the conversation did not want to be disturbed. The woman's ridiculous answer in the monologue made the audience laugh. This laughter even more strong when comic demonstrated monologues part where the woman suddenly forget her name, "what about your name? "I cannot memorize my name".

\section{The creation technique of humor discourse through verbal joke}

According to Berger (1993), creation technique of humor discourse through verbal joke is the creation of humor discourse by verbally mocking that is usually found in intelligent dialogue. The word 'mock' itself equated with annoying people without offending their shortcomings. Below is a stand-up comedy humor discourse created through verbal joke:

(09) "A child goes to school, he is ordered to bring a machete. When he arrives at school and begins to study, the teacher said: "OK. Good morning, students. Today we are going to learn mathematics. Please prepare your book, pen, and do not forget your machete."

(Data of stand-up comedy discourse, 2016)

Related to Berger's (1993) definition about the creation technique of humor discourse through verbal joke, the comic on the discourse (09) intended to show that he is very familiar on the learning process and the educational situation. In the theory of humor creation through verbal joke, sometimes comics look smart and knowing a situation well. This was reflected in the phrase (09) where the comic highlighted the educational situation in one of regencies in Southeast Sulawesi. The phrase "please prepare your book, pen, and do not forget your machete", of course, becomes amusing for the audience. They found the humorous contradiction where in one hand pupils were asked to prepare their stuffs to begin learning mathematics while in the other hand they were also ordered to prepare machetes to fight with other students from other schools. Humor discourse (09) was not only served as entertainment, but also served as a means of education and social criticism.

\section{The creation technique of humor discourse through sarcasm}

Berger (1993) conveyed that technique of humor creation through sarcasm is the creation of humor by expressing something (objection, annoyance) sharply but concurrently employing humor. This is reflected in the humor discourse of stand-up comedy below.

(10) “OK, friends. Please be quiet. If you cannot be, you will be thrown away."

(Data of stand-up comedy discourse, 2016)

The data of stand-up comedy humor discourse (10) above expresses the sarcasm that impressed as expression of annoyance; however, it was still interpreted as humor by the audience. In common situation, sarcasm is the use of harsh words to commit insults and expressing irritation and anger. Nevertheless, in Indonesian culture and language, sarcasm is widely used to emerge humor. The fragments in humor discourse (10) "If you cannot be quite, you will be thrown away," is just an expression to appease the audience, while the word 'thrown away' shows the intimacy between comic and the audience.

\section{The creation technique of humor discourse through satire}

Berger (1993) had stated technique of humor creation through satire is the creation of humor by embarrassing or spreading the inferiority of something, situation, famous people, or community leaders. This model of humor creation was illustrated in the following fragments (11) below:

(11) "In these present days, there are many people claim to be Bugisnese (one of ethnic groups in Sulawesi). Do you know Wa Abe? She said she is a Bugisnese. According to my grandfather's story, until the end of his life, Wa Abe was never willing to admit that she is a Munanese. One day she encountered someone at a seminar, he asked "what is your name?" "My name is Wa Ode Elisabeth, you can call me Wa Abe." "Are you Munanese?" "Not necessarily." (using Muna's language dialect)

(Data of stand-up comedy discourse, 2016)

The example (11) is actually a very sensitive joke particularly in Indonesian cultural context. It offended certain ethnic group, Munanese (one of ethnic groups in Southeast Sulawesi); however, since it was expressed in the context of humor by employing a satirical language, the offensive meaning became soften. Consequently, the audiences considered it as a humor.

The stand-up comedy humor discourse (11) contained satire or criticism, even led to ridicule Muna ethnic group in Kendari. The ethnic group (Munanese) on the fragments (11) 
was described as having a lower status than Bugis ethnic group (Bugisnese); “According to my grandfather's story, until the end of her life, Wa Abe was never willing to admit that she is a Munanese." "One day she encountered someone at a seminar, he asked, what is your name?" "My name is Wa Ode Elisabeth, you can call me Wa Abe." "Are you Munanese?" "Not necessarily." The words "not necessarily" uttered by Wa Abe violates the agreement maxim in communication as well as violating politeness as proposed by Leech (1982) that in communication there is a fixed formulation in the conversation. In line with Leech (1998), Hymes (1974) stated that in a communication, all context of speech are interrelated. The maxim violation in the fragment invoke humorous atmosphere which emerged laughter.

Furthermore, humor discourse (11) tried to raise a social issue in Kendari. It is commonly acknowledged that some people from Muna ethnic group disprove their ethnic and prefer to identify themselves as Bugisnese because they believe that Bugis ethnic group has better prestige (higher status) than Muna.

In terms of language use, the humor discourse (11) used satire to trigger the laughter by telling the story about a person named Wa Abe - Wa Abe is a moniker for a girl in Muna ethnic group-; however, Wa Abe was too diffident to admit her status as Munanese girl. She was more confident to admit herself as a part of Bugis ethnic. For audiences, the story of Wa Abe contained a ludicrous circumstance which emerge laughter.

\section{The creation technique of humor discourse through sexual satire}

Berger (1993) proposed that creation technique of humor discourse through sexual satire is the creation of humor by making references or satire devoted to sexual matters. Below is a stand-up comedy humor discourse created through sexual satire:

(12) "I am suspicious. I am suspicious about examination procedure conducted by Police Department in policewoman recruitment. For example in virginity tests, the examiner is testing the woman virginity by sound check, check, one, two, check, one, two. He then suddenly laughs, Ha, ha, ha, and exclaims, she is not virgin anymore, she is not virgin anymore! Then people ask, how do you know that? He answers, because I could not hear echoes".

(Data of stand-up comedy discourse, 2016)

Although the fragment (12) is a taboo and sensitive issue, particularly in terms of social and cultural norms in Southeast Sulawesi as well as confidentiality of Police Department, in the context of stand-up comedy humor discourse it becomes commonly acceptable. It is in line with Wijana (2002) who stated that discussing sexual issues is allowed in particular purposes, contexts, or circumstances as illustrated in fragment (12) where the comics used sexual satire to produce humor. He emerged laughter by telling the story of policewoman recruitment procedure where the examiner checking the examinee's virginity -- the virginity check is one of mandatory procedure in policewoman recruitment in Indonesia--. He likened the procedure to the way people check the echo of microphone as illustrated in the phrase "check, check, one, two, check, one, two."

Although the virginity test for new policewoman recruit have been a headline and criticized by many, the sexual satire in this humor discourse is no longer as taboo as 5 years earlier. In fact, some humors today utilize sex as their jokes materials as well. The fragment (12) emerged laughter because comic analogize the virginity test with the echo test on microphone. On behalf of the audiences, especially teenagers, it implied porn; however, the implication became soften and produced laughter due to the comic ludicrous analogy.

\section{The creation technique of humor discourse through deception}

According to Berger (1993), creation technique of humor discourse through deception is a technique conducted by defeating one's intelligence by emerging humorous statements or asking humorous questions. The comic in humor discourse (13) employed the technique of deception.

(13) “...recently I was in love with a girl. I had been chatting on her via Blackberry messenger for two months; however, this afternoon she asked me the most terrifying question. She asked, "Where are you from?" I want to honestly answer "I am from Wawonii," but then I changed my mind and lied, "Oh, I am from Kendari. And you?" She finally replied "Oh, I am from Wawonii."

(Data of stand-up comedy discourse, 2016)

The fragment (13) describes how the comic is fooled by the situation when he wanted to get close to a woman. The comic who is a native of Wawonii Island tried to disprove his origin, "Where are you from?" I want to honestly answer "I am from Wawonii", but then I changed my mind and lied, “Oh, I am from Kendari. And you?" She finally replied "Oh, I am from Wawonii." In the fragment (13), the comic implied that he was too diffident to concede Wawonii Island as his hometown. In Southeast Sulawesi, Wawonii Island is generally acknowledged as an isolated and underdeveloped area. In the past, it was also famously acknowledged as the source of black magic (witchcraft). The presence of such conditions and stigma, many people from Wawonii Island, particularly youth, feel ashamed and try to disprove their hometown. Although, nowadays, Wawonii Island tends to become a developed area, its conditions in the past are often used as a joke.

When the comic was asked by the girl about his hometown, "dimana kita tinggal (where are you from)?" The word "kita" is adopted from the Bugis language, which is the pronoun for the second singular person. It is usually addressed to a person with high social status or a newly met person. The comic replied "Oh I am from Kendari. And you?" His answer was intended to disprove his hometown by mentioning Kendari, the capital city of Southeast Sulawesi, as his hometown. Unfortunately, his answer made him fooled because the girl, unexpectedly, also came from Wawonii Island, as illustrated in the fragments, "Oh I am from Wawonii". The girl's unexpected answer successfully emerged laughter. The comic implied his embarrassing ex- 
perience and made the audience feel sorry as well as laugh at him. It is in line with Claire's theory (1984), that humor can be created when causing shame.

\section{CONCLUSION}

The development of Stand-up comedy in Indonesia is influenced by the existence of traditional arts from Java Island or other Islands in Indonesia. It influences the comics' humor material and language use in their stand-up comedy performance. Specifically, stand-up comedy humor discourse is accepted locally. It can be considered and accepted as a humor in one area but can also be not accepted as a humor in the other area or circumstances.

In terms of humor creation, the stand-up comedy humor discourse in this research are in line with the concepts and theories of humor discourse creation techniques in general, they are: (a) rhetoric, (b) tone variation, (c) irony, (d) language misunderstanding, (e) wordplay, (f) verbal jokes, (g) sarcasm, (h) satire, (i) sexual satire, and (j) deception. Furthermore, the findings showed that the most commonly used of creation techniques were wordplay, rhetorical, and deception. These three techniques are more uttered than other techniques since the local comics are still lack of public speaking ability.

\section{REFERENCES}

Ambarwati, A. (2016). Wacana Humor dalam Cerita Lupus Kecil. Disertasi, Program Studi Pendidikan Bahasa Indonesia. Disertasi, Program Studi Pendidikan Bahasa Indonesia Pascasarjana.Universitas Negeri Malang. Pembimbing (I) Prof. Dr. Maryaeni, M.Pd.,Pembimbing (II) Prof. Dr. Suyono, M.Pd., Pembimbing (III)

Badara, A. (2013). Analisis Wacana: Teori Metode, dan Penerapannya pada Wacana. Media. Jakarta: Kencana Prenada Media Group. (Cetakan kedua).

Berger, A. (1993). An Anatomy of Humor. New York: Transaction Publisher.

Berger, A. (1998). Signs in Contemporary Culture: An Introduction to Semiotics. Published: Sheffield Pub Co.

Claire, E. (1984). What's so Funny. Rochelle Park Pub.

Creswell, J. W. (1994). Resaearch Design: Copy Quantitative \& Qualitative Approaches. California: Sage Publication.

Crystal, D. (1987). Toward a "bucket" Theory of Language Disability: Taking Account of Interaction Between Linguistic Levels. Clinical Linguistics and Phonetics I, 7-22.

Greenbaum, A. (1999). Stand U Comedy as Rhetorical Argument: An Investigation of Comic Culture. International
Journal of Humor Research. Published Online: 2009-0717. DOI: https://doi.org/10.15151/humr.1999.12.1.33

Hymes, D. (1974). Foundations in Sociolinguistics: An Ethnographic Approach. Philadelphia: University of Pennsylvania Press.

Leech, G. (1982). Principles of Pragmatics. London and New York: Longman.

Martin, R. A. (2007). The Psychology of Humor: An Integrative Approach. London: Elsevier Academic Press.

Raskin, V. (1985). Semantic Mechanisms of Humor. Dordrecht \& Boston \& Lancaster: Reidel Publishing Company.

Raskin, V., \& Attardo, - (1991). Semantic Mechanisme of Humor. Dordrecht Holland: D. Reidel Publishing Company

Rodasaut. (2013). “Apa Itu Stand Up Comedy?” http://rodasaut.blogspot.com/2013/01/apa-itu-stand-upcomedy. html. Rustono. 1998. "Implikatur Percakapan sebagai Penunjang Pengungkapan Humor di dalam Wacana Humor Verbal Lisan Berbahasa Indonesia". Disertasi UI Jakarta.

Setyaningsih, N. (---). Ethnic Stereotypes in Stand up Com$e d y$. Prosiding the 5 th International Confrence on Indonesian Studies: "Ethnicty and Globalization"

Soedjatmiko, W. (1992). "Aspek Linguistk dan Sosiokultural di dalam Wacana Humor" dalam Bambang kaswanti Purwo (ed.). Pelba 5. Jokyakarta: Kanisius.

Sudaryanto. (1993). Metode dan Aneka Teknik Analisis Bahasa. Yogyakarta: Gadjah Mada University Press

Siwi, N.F. (2016). Pola Humor dalam Tuturan Serial "Stand Up Comedy" di Kompas TV 12 Maret dampai dengan 28 Mei 2015. Bachelor Thesis, Universitas Muhammadiyah Purwokerto. URL http://repository.ump.ac.id/id/ eprint/904.

Van Dijk, Teun (ed.) (1997). Discourse as Social Interaction: Discourse Studies A Multidiciplinary Introduction. Vol. 2. London: Sage Publication. 1997.

Wilson, Ch. (1979). Jokes From Content Use and Function. New York: Academic Press.

Wijana, I D. (1996). “Wacana Kartun dalam Bahasa Indonesia" Prisma, No. 1, Hlm. 4.

Wijana. I D.(2000). "Pornografi dan Asosiaasi Pornogragfi pada Judul Artis Harian Berita Nasional Yogjakarta" dalam Makalah, Yogjakarta: Fakultas Ilmu Budaya, Universitas Gadjah Mada.

Wijana, I D. (2003a). Permainan Bahasa dalam Rangka Meningkatkan Mutu Pengajaran Ilmu Bahasa Indonesia: Yogyakarta.

Yuniawan, T. (2005). Teknik Penciptaan Asosiasi Pornografi dalam Wacana Humor Bahasa Indonesia. Jurnal Humaniora, 17(3), 285-292. 